Revue Française de Civilisation Britannique

\title{
Political Commitment of a New Type? Red Wedge and the Labour Party in the 1980s
}

Un engagement politique d'un genre nouveau? La campagne Red Wedge et le Parti travailliste dans les années 1980

Jeremy Tranmer

\section{(2)enEdition} Journals

Electronic version

URL: http://journals.openedition.org/rfcb/1466

DOI: $10.4000 /$ rfcb.1466

ISSN: 2429-4373

Publisher

CRECIB - Centre de recherche et d'études en civilisation britannique

Electronic reference

Jeremy Tranmer, « Political Commitment of a New Type? Red Wedge and the Labour Party in the 1980s », Revue Française de Civilisation Britannique [Online], XXII-3 | 2017, Online since 05 July 2017, connection on 02 May 2019. URL : http://journals.openedition.org/rfcb/1466 ; DOI : 10.4000/ rfcb.1466

This text was automatically generated on 2 May 2019.

\section{cc) (†) $\odot$}

Revue française de civilisation britannique est mis à disposition selon les termes de la licence Creative Commons Attribution - Pas d'Utilisation Commerciale - Pas de Modification 4.0 International. 


\title{
Political Commitment of a New Type? Red Wedge and the Labour Party in the 1980 s
}

\author{
Un engagement politique d'un genre nouveau? La campagne Red Wedge et le \\ Parti travailliste dans les années 1980
}

Jeremy Tranmer

\section{Introduction}

1 Many British popular musicians protested against the Thatcher governments in the 1980s. ${ }^{1}$ The Specials sang about youth unemployment in "Ghost Town", the Beat called for the Prime Minister's resignation in "Stand Down, Margaret", and Kirsty MacColl criticised her policies in "Free world". The Redskins, Billy Bragg and the Style Council played at benefit concerts to raise money for striking miners. In 1985, Billy Bragg and Paul Weller participated in the creation of Red Wedge, a movement which aimed at interesting young people in politics and encouraging them to support the Labour Party. In the following two years, it attracted the support of well-known, successful artists such as the Communards, Lloyd Cole and the Smiths. It worked tirelessly for Labour, before being finally wound up in 1990. Although Red Wedge was the only coordinated attempt by musicians to support a major British political party and it attracted a great deal of media attention in the mid-1980s, relatively little has been written about it since. ${ }^{2}$ The academics Simon Frith and John Street have compared it to previous attempts to mobilise musicians in favour of a political cause ${ }^{3}$, as has Yasmine Carlet. ${ }^{4}$ The journalists Robin Denselowe, John Harris and Dorian Lynskey have all touched on it in broader studies of music and protest in Great Britain. ${ }^{5}$ Red Wedge has also been briefly mentioned in the biographies and autobiographies of musicians involved in it, including those of Billy Bragg, Paul Weller and Richard Coles. ${ }^{6}$ It is, however, rarely referred to in work about Labour politicians who came into close contact with it, such as Neil Kinnock and Peter Mandelson. ${ }^{7}$ What all these pieces of work have in common is that they tend to focus on the overall political 
objectives of Red Wedge and conclude that they were not achieved since Labour lost the 1987 general election. This article will suggest that Red Wedge attempted to develop new forms of political commitment for musicians based on cooperation and involvement in the running of the movement. It will firstly present Red Wedge and its activities before suggesting that they have to be understood in the context of a growing interest in political issues among musicians from the late 1970s to the late 1980s, resulting in musicians associating themselves with campaigns mounted by sections of the British left. It will then examine the new forms of activism encouraged by Red Wedge and the obstacles the movement faced in putting them into practice. Since relatively little has been published about Red Wedge and activism, this paper will draw heavily on documents found in the movement's archives and articles published in its quarterly magazine Well Red. ${ }^{8}$

\section{Red Wedge and musicians' support for Labour}

2 Red Wedge was founded at the House of Commons in November 1985 in the presence of Billy Bragg, Paul Weller, Jerry Dammers and other musicians, as well as Labour politicians including Neil Kinnock, Ken Livingstone, Claire Short and Robin Cook. Although the Labour Party gave it an office at its headquarters and, along with the National Union of Public Employees (NUPE), granted it a loan, Red Wedge defended its autonomy. It published its own documents and defended positions which were not identical to those of Labour. It sought not simply to reflect the views of the Labour Party, but to influence Labour's policies, "pressing Labour to develop positive and up-to-date policies on issues that directly affect young people; Youth Training Schemes, educational grants, benefits, job creation." 9 In a written presentation of the movement intended for Labour Party members, Red Wedge defined itself as an "independent broad left alliance [...] committed to making sure that young people are better informed about politics in general, and democratic socialist alternatives to Conservatism in particular" and described its relationship with Labour as being one of "just good friends!" 10 Red Wedge brought together musicians, comedians, media workers and activists, but artists were allowed to have the final say concerning the running of the organisation. ${ }^{11}$ It had an office manned by a small staff in Labour's headquarters, while meetings about strategy and activities were regularly held, involving musicians such as Bragg and Weller. Its main non-musical public face was the movement's Political Coordinator Annajoy David, who had previously worked for the youth wing of the Campaign for Nuclear Disarmament. Volunteers included Press Coordinator Neil Spencer, who had previously been the editor of the New Musical Express. Red Wedge did not aspire to be a traditional political organisation and took as its model independent record labels, which it viewed as being capable of reacting rapidly, flexibly and imaginatively to changing circumstances. ${ }^{12}$

Red Wedge launched itself into a variety of activities. An eight-date national tour took place in January 1986. In each town or city where the tour stopped, debates involving young people, musicians and Labour politicians were held in the afternoon, while a concert was organised in the evening. Labour MPs were encouraged to attend the evening event and to mingle with young people, engaging in discussion with them. ${ }^{13}$ Red Wedge worked closely with trade unions, organising performances of music at union events and generally attempting to make unions more attractive and relevant to young people. It organised youth forums bringing together members of the Labour Party, trade unionists 
and young people. It also published a series of pamphlets, ${ }^{14}$ as well as a regular quarterly magazine, Well Red, which carried articles about music and politics, interviews with musicians who were interested or involved in left-wing politics, concert and album reviews, and information about Red Wedge's activities. The first edition of Well Red set the tone for the others. In "Red and Black", Kevin Ainsleigh examined the history of political dance music; "Wedge world" gave information about Red Wedge's activities; and there were interviews with the trade unionist Brenda Dean and with a member of Madness. ${ }^{15}$ Members of Red Wedge appeared in a party political broadcast by the Labour Party which was aired on the main television channels.

The movement was particularly active before and during the 1987 general election campaign, when it published its own 12-page manifesto entitled Move On Up. A Socialist Vision of the Future. With a foreword written by Labour leader Neil Kinnock, the manifesto presented Red Wedge's approach to a number of themes - human rights, employment and jobs, housing, education, defence, culture - and also added other proposals that it hoped Labour would "take on board". ${ }^{16}$ The manifesto ended with a brief definition of Red Wedge's view of socialism and of the Labour Party:

For us, socialism stands for dignity, compassion and independence. And the right to decide the way we live our lives. In this election year, we believe a Labour government is our only chance to make our voices heard. To escape from the Tories' grim no-hope Britain. A Labour government is only the beginning. Labour doesn't have all the answers. But Labour can offer us a brighter future, and the chance to change things for ourselves. So ... Don't Get Mad, Get Organised. ${ }^{17}$

Red Wedge embarked upon a tour of marginal constituencies. The core musicians travelled together from town to town by bus and were joined by others who performed only occasionally. Led by Bragg and Weller, the tour brought together, among others, Jimmy Somerville (of the Communards and formerly of Bronski Beat), Jerry Dammers (formerly of the Specials), Working Week, Madness, Heaven 17, Fine Young Cannibals, Level 42 and Lloyd Cole. A comedy tour was also organised involving Lenny Henry, Ben Elton, Robbie Coltrane, Craig Charles, Phil Jupitus and Harry Enfield.

Despite an improvement in its youth vote, Labour lost the election. Members and supporters of Red Wedge were hugely disappointed, having believed that they could help Labour to victory. ${ }^{18}$ Some dropped out of political activity, distancing themselves from Labour. Paul Weller, for example, criticised it for being slow and unresponsive, adding that the press was more interested in his political views than in his music and that his career had suffered..$^{19}$ As a result, it is widely assumed that Red Wedge disappeared after the elections. ${ }^{20}$ However, it continued to exist for another three years. During this time, it continued to work with the Labour Party and mounted the "Get Busy" initiative as part of the "Labour' Listens" campaign in 1988. It also worked closely with the trade union movement, organising a concert entitled "A Night for the NHS" in March 1988 with NUPE and the Confederation of Health Service Employees (COHSE), for example. It devoted a great deal of time trying to sign a deal with record companies in order to release a benefit album. However, this came to nothing, adding to the movement's growing financial crisis. It also became involved in local musical projects in towns such as Dudley. ${ }^{21}$ The final edition of Well Red came out in 1990 (18 months after the previous edition), but it was admitted that "the only part of the organization still functioning is this magazine". ${ }^{22}$

Red Wedge's demise was the result of the widespread disillusionment caused by the 1987 general election defeat, serious financial difficulties which limited the movement's 
potential projects, and the changing musical/cultural context. In the words of a contributor to Well Red at the end of 1988 , the music scene was increasingly dominated by "mindless psychedelic clubbing", as use of the drug ecstasy became more widespread in the United Kingdom. ${ }^{23}$ The new context was reflected in the changing media coverage of Red Wedge. The New Musical Express, for example, virtually ignored the movement after 1987.

\section{A product of its times}

Red Wedge did not appear out of thin air and was the product of cultural and political developments that had been taking place since the mid-1970s, when some musicians began to take a close interest in politics. In 1976, music-lovers and activists, some of whom were members or sympathisers of the Socialist Workers Party (SWP), created Rock Against Racism (RAR) in response to racist comments made by the guitarist Eric Clapton. ${ }^{24}$ They had also been shocked by Nazi salutes given by David Bowie, the use of swastikas by punks, the increasing number of racist attacks, and the rise of the far-right National Front, and they decided to try to use music as a means of fighting back against racism and fascism. RAR focused on punk and reggae, which were deemed to be more subversive and less commercial than other genres and to symbolise racial unity when combined. Consequently, many RAR concerts featured both punk and reggae bands. This approach caught the imagination of young people, and in the following years RAR became a dynamic grassroots movement, spreading and benefiting from the "Do It Yourself" spirit of punk, whereby young people were encouraged to take matters into their own hands and to take control of their lives rather than wait for others to act for them. It published the magazine Temporary Hoarding, produced numerous leaflets and posters, put on hundreds of local concerts, and organised several regional carnivals and two national carnivals held in London in $1978 .{ }^{25}$ The first national carnival featured Aswad, the Clash, Patrick Fitzgerald, Steel Pulse, the Tom Robinson Band and X-Ray Spex, and Aswad, Elvis Costello and the Attractions, Misty in Roots, and Sham 69 performed at the second. As punk ceased to be a mass movement in the late 1970s, RAR gained the support of antiracist Two-Tone bands such as the Specials and post-punk groups including the Gang of Four. In 1979, it mounted a "Militant Entertainment" tour of constituencies where the National Front was standing candidates to try to mobilise young people against them. In the course of the tour, forty bands performed at twenty-three concerts. ${ }^{26}$ The far-right candidates were heavily defeated, and RAR's last major initiative was a regional carnival in Leeds in 1981, after which it quickly disappeared. It appeared to have achieved its objectives, and many activists became involved in various movements against Thatcherism.

9 RAR led to renewed interest in politics among musicians and sections of the music industry. The weekly New Musical Express newspaper, for example, supported RAR and covered its activities. ${ }^{27}$ Yet most musicians' active involvement was relatively limited since they simply performed at concerts and expressed their support for RAR in interviews with newspapers and fanzines. The activities of the members of the Clash, who took part in a picket of the headquarters of the National Front, and of Tom Robinson, who attended RAR meetings and included the organisation's founding statement on the sleeve of his 1978 album Power in the Darkness, are exceptions to the general trend. Nevertheless, RAR created a precedent which inspired musicians in the 1980s, particularly as some of them attended RAR's carnivals. As Billy Bragg has noted: 
That first ANL/RAR carnival was a watershed, setting the tone for the decade to come. Those of us who were there that day would go on to support the Two-Tone movement, the miners, CND, anti-apartheid, Nicaragua, Red Wedge, the GLC, Live Aid. It was the moment when my generation took sides. ${ }^{28}$

Moreover, Red Wedge was also shaped by punk. Although by the mid-80s punk no longer existed as a mass sub-culture, Bragg, Weller, Robinson and others had been involved in it and influenced by it. In particular, they embraced the "Do It Yourself" (DIY) ethic of punk, the decision to create Red Wedge being a good example of this. Red Wedge's hope to break down boundaries between musicians and young people can be seen as an evolution of the punk movement's desire to reduce the distance between performers and their audience.

11 Red Wedge was also, to a certain extent, the product of the widespread opposition to Thatcherism expressed in various ways by musicians from the late 1970 s onwards. ${ }^{29}$ Numerous groups wrote songs criticising Margaret Thatcher and her policies and presenting the impact they had on British society. One of the most famous and commercially successful songs was 'Ghost Town' by the Specials, which compared the depressing situation of young people in the early 1980s with the pleasure they had had in the period before mass unemployment. The song reached number one in the charts in June 1981, a time when riots were breaking out throughout the country, and stayed in the charts for 14 weeks. Other songs about unemployment include "One in Ten" by the aptlynamed group UB40 $0^{30}$ and "2 million voices" by the Angelic Upstarts. Elvis Costello wrote "Shipbuilding" about the Falklands War, and a version of the song performed by Robert Wyatt entered the charts. Pink Floyd's album The Final Cut contained several references to the war, especially in the song "Get Your Filthy Hands Off My Desert", while Crass railed against the conflict in "Sheep Farming in the Falklands" and "How Does It Feel To Be The Mother of 1,000 Dead?" The miners' strike of 1984/85 was the subject of large number of songs, for example "Soul Deep" by the Council Collective, "Keep On Keepin' On" by the Redskins, or "Strike" by the Enemy Within. To protest about the Community Charge, the Exploited recorded "Don't Pay the Poll Tax" and Simple Minds wrote "Soul Crying Out". In "No Clause 28", Boy George demanded the abolition of a section of the Clause 28 of the 1988 Local Government Act which discriminated against homosexuals. Artists such as the Redskins and Billy Bragg did not simply express themselves in their music, but they frequently used interviews with the music press, especially the New Musical Express to voice their political opinions ${ }^{31}$, while Paul Heaton of the Housemartins insulted her in a concert that was broadcast live on national radio. ${ }^{32}$

Raising money for movements or sections of the population that were involved in disputes with the government was a frequent activity for many musicians. The Beat, The Clash, Peter Gabriel, Madness and others each contributed a song to a benefit album for the Campaign for Nuclear Disarmament. The proceeds from the singles "Soul Deep" and "Strike" were donated to striking miners and their families, as was the money raised from various benefit albums including Dig This - A Tribute To the Great Strike with songs by groups influenced by punk such as Chumbawamba, the Mekons, the Men They Couldn't Hang and Poison Girls. Commercially successful groups like Bronski Beat, the Clash, New Order, the Style Council and Wham! performed at benefits for the miners. Billy Bragg, Paul Weller, Jimmy Somerville of Bronski Beat and others also picketed with miners. ${ }^{33}$

13 Some musicians had criticised the Labour government of James Callaghan in the late 1970s. For example, in “Time for Truth", the Jam lamented the decline of Britain under “ 
Uncle Jimmie". Yet in quantitative and qualitative terms, the opposition of musicians to Margaret Thatcher and her governments was markedly different to what had come before. This opposition was not organised. The term "Rock Against Thatcher" was occasionally used, particularly in the very early 1980s, but there was no attempt to coordinate activities by creating a national movement. Moreover, until the foundation of Red Wedge, opposition to Thatcherism was rarely expressed in terms of support for the Labour Party. The 1983 general election was a partial exception to this since, when asked by the New Musical Express, several musicians such as Marc Almond of Soft Cell, Mari Wilson, Ben Watt of Everything But The Girl and Roddy Frame of Aztec Camera, admitted that they would be voting Labour. ${ }^{34}$ The miners' strike saw many musicians openly critical of the leadership of the Labour Party for its lukewarm support for the National Union of Mineworkers. Nevertheless, the defeat of the miners' strike had a profound impact on Billy Bragg and Paul Weller, convincing them that Margaret Thatcher had to be defeated at the next general election, which entailed supporting the Labour Party.

Sections of the labour movement had begun taking a close interest in popular music in the mid-1970s. As mentioned above, members of the SWP had played an important role in the foundation of RAR. They had also followed closely the emergence of punk and come to believe that it was an expression of working class revolt and could be harnessed to a revolutionary political project. Consequently, Socialist Worker, the SWP's weekly paper, published debates about punk and numerous articles about punk bands. ${ }^{35}$ In the run-up to the 1979 general election, the Labour Party had sought to profit from the success of RAR and published adverts in the music press, including one which read "Don't Just Rock Against Racism. Vote Against It. Vote Labour. ${ }^{36}$ In the early 1980s, benefit concerts were an integral part of the Trade's Union Congress's People's March for Jobs and the SWP's Right to Work Campaign. Under the leadership of Ken Livingstone between 1981 and 1986, the Labour-controlled Greater London Council sponsored numerous concerts throughout the capital which often had a political theme. The largest of these were the "Jobs for a Change" festivals of 1984 and 1985. The first attracted, among others, Aswad, Billy Bragg, Misty in Roots, the Redskins and the Smiths, and Billy Bragg, the Communards, The Men They Couldn't Hang, and the Pogues performed at the second. Billy Bragg also performed at the "Farewell to the GLC" concert, the last major event organised by the council before its abolition. The GLC's concerts and festivals, many of which were free, attracted large numbers of young people who were exposed to left-wing political ideas that were rarely present in the mainstream media.

In 1983, Neil Kinnock became leader of the Labour Party. Aged forty-one, he was considerably younger than previous leaders and enjoyed folk music as well as rock'n'roll. The age and musical tastes of Kinnock made him see music as a way of reaching out to young people and paved the way for a coming together of musicians and the Labour Party ${ }^{37}$ In 1984, Kinnock appeared in the video for Tracy Ullman's single "My Guy". During a meeting between Kinnock and Bragg, it was decided that the latter should organise a tour to popularise Labour's policies for young people. Several months later he embarked on the "Jobs For Youth" tour, which was part of Labour's Job and Industry Campaign. MPs such as Robin Cook attended the concerts ${ }^{38}$ Labour's changing approach to popular music received support from some Marxists, particularly those sympathetic to the ideas expressed in the Communist Party of Great Britain's monthly journal Marxism Today. For instance, Stuart Hall, using Antonio Gramsci's concept of hegemony, stressed the importance of popular culture in the struggle against Thatcherism. ${ }^{39}$ 

by the success of Band Aid and Live Aid. Band Aid, a collection of the best-known British musicians of the mid-1980s brought together by Bob Geldof, recorded the song "Do They Know It's Christmas" in 1984 to raise funds in order to alleviate famine in Ethiopia. The following year Geldof organised the Live Aid concerts in London and Philadelphia. These events tapped into a British history of charity and followed on from previous attempts made by musicians to raise money, for example George Harrison's concert for Bangladesh in 1971 and Paul McCartney's concerts for Kampuchea held in London in 1979. Artists such as Paul Weller were involved in both Band Aid/Live Aid and more political activities including Red Wedge. The latter has been described as the child of Live Aid..$^{40}$ This is, however, a little simplistic as it plays down the significance of the history of musicians' political activities which preceded Live Aid. It would be more appropriate to see the relationship between musicians' political activities and Live Aid as being dialectical. The former created a context in which the latter could emerge, while Live Aid reinforced the credibility of musicians as well as strengthening the belief among artists, such as Weller, that they could have a positive impact on the world around them and bring about change. 41

Once Red Wedge has been situated in a broader musical and political context, its emergence appears less surprising. Nevertheless, its appearance was not inevitable but resulted from a particular set of circumstances in which the actions of politically-minded musicians reinforced changing attitudes in the labour movement. It should be noted that, before Red Wedge, musicians' commitment to a general cause or to opposition to the Thatcher governments had been mainly limited to their traditional spheres of activity, that is playing at concerts and recording music.

\section{New forms of commitment for musicians}

18 Although Red Wedge's public statements concentrated on its aim of contributing to a Labour victory against the Conservatives, its internal documents suggest that the main participants in Red Wedge hoped to create a new type of movement. At the heart of this vision was the belief that new roles and new forms of commitment for musicians could be pioneered. These were based on cooperation between musicians, their active involvement in all aspects of Red Wedge, and a new relationship between musicians and Labour activists/politicians.

Much of the Red Wedge project was based on close cooperation between the musicians who became involved in it. Musicians were expected to work together to further the political aims of the movement. This approach can be illustrated by two examples. The national tour of January 1986 was the first major public event organised by Red Wedge and took in seven concerts in different parts of Britain (Manchester, Cardiff, Birmingham, Leicester, Bradford, Edinburgh and Newcastle). Several artists performed at all seven concerts (D.C. Lee, Lorna Gee, Billy Bragg, The Communards, the Style Council and Jerry Dammers), while others joined them all along the way. The ever-present musicians travelled together on a coach and stayed in the same accommodation. This form of organisation was repeated on other tours mounted by Red Wedge. It should be borne in mind that a tour involving several groups and lasting a week was relatively unusual. RAR's 1979 Militant Entertainment tour was longer but organised differently. Three groups toured together and performed at the same concerts for three consecutive nights,

Revue Française de Civilisation Britannique, XXII-3 | 2017 
and then they were replaced by three different bands. ${ }^{42}$ As it was noted at the time, the Red Wedge tour was more similar to the Motown Review tours of the early 1960s when artists such as Smokey Robinson, Marvyn Gaye, Stevie Wonder and Martha and the Vandellas toured the United States together. ${ }^{43}$ Despite the unusual nature of the Red Wedge tour, there appears to have been no serious problems between the various musicians. According to the press officer Neil Spencer, "[t]he atmosphere on the bus was electric" and "[e]verybody left their egos at the door of the bus and mucked in". ${ }^{44}$ Tom Robinson has also stated that "[t]he artists got along very well" and that "[t]here was a real sense of solidarity". ${ }^{45}$

The second example of cooperation between musicians concerns the concerts themselves and the song "Move On Up". As well as being the title of Red Wedge's election manifesto, it was performed collectively as a finale at gigs. ${ }^{46}$ The choice of "Move On Up" had several advantages for Red Wedge. It resulted partly from the musical tastes of some of the leading figures of the movement. Paul Weller was particularly interested in soul, as had become increasingly apparent after he left the Jam and founded the Style Council. Even before leaving the Jam, the group had recorded their own version of "Move On Up" in 1983 and frequently performed it at concerts. Although his music was mainly influenced by punk and folk, Billy Bragg also had a keen interest in soul, as did some of the other artists who associated themselves with Red Wedge such Jimmy Somerville. Soul was therefore a potential common denominator for a group of musicians with different musical tastes. However, what is particularly interesting is the fact that musicians performed the song together. It was relatively uncommon for musicians from different bands to play together and share the limelight during a concert. Although musicians had sometimes jammed together at RAR concerts and Jimmy Pursey of Sham 69 had famously sung "White Riot" with the Clash at the first RAR carnival, it was far from systematic. It allowed Red Wedge to embody the unity of young people, irrespective of their sex, class, sexuality and race, against Margaret Thatcher and to offer a symbolic challenge to the individualism advocated by the Prime Minister.

The ability of Red Wedge to foster a cooperative approach among musicians was far from certain as it entailed overcoming the competitive individualism of the music industry. Musicians' careers were highly individualised. Aspiring musicians hoped to sign a contract with a record company in order to turn professional and to make records. They therefore had to be noticed by a record company. This meant that they were in competition with other bands. Once they had a signed a contract, their records had to be commercially successful so that their record company would continue to employ them. Further competition was created as bands sought to ensure that their records reached as high a position as possible in the charts. This situation was exacerbated by the gang mentality that some bands adopted in their attempts to achieve their aims. During tours, well-known bands often guarded their status jealously by complicating matters for their support acts (for example, ensuring that the sound of the support acts was quieter than their own). The competition between artists could even be present during activities for a political cause as is illustrated by the case of the first RAR carnival. The Clash and the Tom Robinson Band had emerged from the "highly competitive punk scene" and argued over which group should headline the event (the Clash had a large punk following, while the Tom Robinson Band had already performed at numerous RAR concerts). ${ }^{47}$ The Tom Robinson Band prevailed. When the Clash performed, they could hardly be heard at the back of the crowd. The Tom Robinson Band, however, could be heard much clearly, 
allowing them to reinforce their status as the headline act. ${ }^{48}$ Given the structural competitiveness of the music industry and the egotistical attitudes that it encouraged, Red Wedge's attempts to create an approach based on cooperation was quite successful.

Red Wedge also tried to encourage musicians to participate in all aspects of the movement. This could be seen in three areas. Firstly, they were expected to attend, on a regular basis, internal meetings of the movement, such as those of the Steering Committee. They also had to attend press conferences when new events were launched or during tours. Finally, they were encouraged to attend daytime meetings with young people during tours. In other words, one of the specificities of Red Wedge was that musicians were not simply asked to play at concerts. However, this attitude to the involvement of musicians proved to be problematic in several ways. The minutes of internal meetings show that, although Billy Bragg, for example, regularly went to meetings, many other musicians were rarely present. This created tension with Red Wedge staff who complained about it. For instance, in April 1987 members of the staff noted that many musicians had showed no interest or commitment for six months and no inclination to participate in fundraising. ${ }^{49}$ Moreover, not all musicians were temperamentally suited to the more mundane tasks of Red Wedge. According to the journalist Paolo Hewitt who was actively involved in Red Wedge, Paul Weller became frustrated with internal meetings which "got bogged down in tedious detail". ${ }^{50}$

It is important to remember that musicians had particular professional obligations: recording studios had to be hired, time had to be spent promoting records (being interviewed by the press, signing albums in music shops etc.), tours had to be organised a long time in advance and could lead to musicians being absent for weeks or even months at a time. As a result, it was difficult for musicians to have a political activity that involved regular commitments. In other words, for practical reasons, many musicians could not be like ordinary activists. It is therefore hardly surprising that few turned up regularly for internal meetings. Conflicting schedules could also create problems for Red Wedge's public activities, leaving musicians with a stark choice. For instance, given that the United Kingdom did not then have fixed-term parliaments, Red Wedge had only a limited amount of time to organise its 1987 election tour, and Billy Bragg had to cancel a tour of Japan in order to participate. ${ }^{51}$

As Yasmine Carlet has briefly noted, although Red Wedge was an activist movement, many of those associated with it had little experience of activism and/or simply wanted to show their political preferences. ${ }^{52}$ It is quite clear that the musicians in question were far from forming a homogenous group. Bragg (Labour Party), Jimmy Somerville (Labour Party Young Socialists), Robert Wyatt (Communist Party of Great Britain) and Tom Robinson (gay rights and RAR), for example, were among the only musicians to have had some experience of activism. Those with little or no experience were no doubt less aware of the level of commitment they were being asked to make and less able to participate in activities that were not directly related to music. Weller, for example, also felt "out of his depth" in press conferences when "questions rained down on all sides". ${ }^{53}$

Red Wedge tried to develop a new relationship between musicians, on the one hand, and activists and politicians, on the other. Billy Bragg had already pioneered this new relationship during his 1985 Jobs for Youth tour. It was preceded by a meeting in the House of Commons during which he gave instructions to MPs who were to be present at his concerts. The MPs, who were "more apprehensive than the singer", were told by Bragg: " [y]ou're not there to make speeches, but to be around so that people can talk to you if they want to 
". ${ }^{54}$ The MP Robin Cook even asked Bragg what he should wear. ${ }^{55}$ In a document sent to Labour Party members who might attend a concert, Red Wedge issued similar instructions. It made it clear that there were to be "no speeches, [...] no lecturing and no crass electioneering from the stage" and that "political statement should be made by politicians in local press conferences before the concerts." ${ }^{66}$ The document also advised Labour politicians how to make sure they were recognised: "I know it sounds foolish but wearing a badge with your name on it is a great help in allowing potential Labour supporters to identify you." ${ }^{57}$ It was thus quite clear that, although they hoped that their actions would help Labour to victory locally and nationally, the musicians were not supporting politicians in a deferential way. They assumed that politicians could learn from them and should give way to their greater knowledge and experience of young people.

This relationship was also reflected in the way Red Wedge as a whole interacted with the Labour Party. As mentioned above, Red Wedge attempted to maintain its autonomy. This resulted from the belief that Labour was far from perfect and that its policies regarding young people and culture needed to be improved. Red Wedge believed that it had a role to play in developing party policy in these areas. It therefore refused to give passive, blanket support to Labour. ${ }^{58}$ It was also a way of maximising musicians' support for Red Wedge. In general terms, leading figures in Red Wedge were to the left of the Labour leadership. Bragg and Weller had been highly critical of Labour during the miners' strike, while Jimmy Somerville and others were admirers of Ken Livingstone. They were consequently loath to give unconditional and uncritical support to Labour but were pragmatic enough to accept that Labour was the only electoral alternative to the Conservatives..$^{59}$

Although its arm's length relationship with the Labour Party allowed it to gain the support of many musicians, it also created practical problems. Some of these became apparent during the campaign for the Fulham by-election of 1986 and were discussed at a meeting at the Labour Party headquarters after the election. ${ }^{60}$ Attendance at an afternoon event was low as confusion between Red Wedge and the local Labour Party over who was distributing leaflets to advertise the event led to very few being handed out. At a concert organised by Red Wedge, Labour Party volunteers were unhappy about having to carry sound equipment up and down stairs because not enough Red Wedge supporters were present. It is concluded in the minutes of the meeting that, "[m]any of the problems in Fulham were caused by the fact that it was never made absolutely clear who was responsible for what". The local Labour Party was also unhappy about some of the ideas floated by Red Wedge during the campaign because they would have led to Labour exceeding the legal spending limits and the result possibly being overturned. It noted that, "[ $t$ ]here is work to be done making sure that people on the Red Wedge side understand the special circumstances which apply in by-elections." Red Wedge's unorthodox approach to politics prevented it from engaging fully with the Labour Party.

Another difficulty linked to Red Wedge's status concerned its relationship with the Labour Party Young Socialists (LPYS), the party's official youth movement. At the time, the leadership of the LPYS was dominated by members of Militant, a Trotskyist organisation which was highly critical of the general direction of the party and advocated more combative forms of opposition to the Thatcher governments, as exemplified by the approach of the Militant-dominated local council in Liverpool. However, the national Labour leadership was hostile to Militant and was in the process of expelling its members. The two movements were, to a certain extent, in competition for the support of young people, creating a certain rivalry between them based on different forms of legitimacy. 
The LPYS was a democratic organisation with a representative on the party's National Executive Committee, while Red Wedge had the support of the leadership and the potential capacity to reach out beyond the usual audience of the labour movement. Consequently, Red Wedge became caught up in the conflict between the Labour leadership and the LPYS. For some in the Labour Party, Red Wedge was a means of diverting young people away from the LPYS ${ }^{61}$ Billy Bragg, Neil Spencer and others also believed that the LPYS were deliberately sabotaging their movement and its events by falsely advertising the presence of Paul Weller. ${ }^{62}$ Once again, Red Wedge's unusual, hybrid status was a source of complicated its relationship with Labour.

A close examination of Red Wedge reveals that it attempted to develop a collective approach to its political activities, to make musicians active participants and to create a movement that did not simply support Labour in a passive way. This attempt was partially successful. Musicians cooperated with each other and managed to impose their vision of how events should be organised on activists and politicians. Labour's desperate need to reach out to young people created favourable conditions for Red Wedge to have some of its demands accepted. However, the involvement of musicians in the everyday running of the movement was limited by the structural constraints imposed by the music industry and the personal preferences of musicians regarding the forms their political commitment took. In addition, Red Wedge was unable to square the circle of maintaining its autonomy from Labour and at the same time participating fully in Labour's activities.

\section{Conclusion}

Studying Red Wedge in terms of the forms of activism it tried to promote is fruitful in three ways. Firstly, it sheds light on the difficulties involved in bringing together musicians for an openly political campaign and in establishing a relationship which is satisfactory for both sides. Secondly, it makes it possible to re-evaluate Red Wedge's record. Red Wedge has often been written off as a complete failure as it did not provide a decisive boost to Labour's electoral fortunes in 1987. Yet it did briefly succeed in encouraging new forms of political commitment for musicians. A more balanced picture of the movement's success and failures thus emerges. Finally, the activities of Red Wedge and the musicians who worked with it can be seen as part of an early attempt at modernising the image of the Labour Party by associating it with young musicians. Although Labour gave more and more consideration to its image in the following years, it never tried to recreate Red Wedge. The party was increasingly centralised, particularly under the leadership of Tony Blair, and could no longer tolerate the existence of an autonomous organisation composed of musicians. In any case, it lost the support of many musicians in the 1990s as a result of its attitude during the war in Iraq and its political evolution. Red Wedge is thus the only example in British history of musicians acting together to support an established political party.

31 Jeremy Tranmer is a senior lecturer at the University of Lorraine where he teaches contemporary British history and politics. He wrote his $\mathrm{PhD}$ about British Communism in the 1980s and has published numerous articles about the radical left, as well as the left's relationship with popular music. 


\section{BIBLIOGRAPHY}

Ainsleigh, Kevin, 'Red and Black', Well Red, 1 (1986), pp. 4-5.

Black, Johnny, “Red Wedge: bringing Labour Party politics to young music fans", Guardian (22 April 2015), https://www.theguardian.com/music/2015/apr/22/red-wedge-bringing-labourparty-politics-to-young-music-fans (consulted 10 June 2016)

Bragg, Billy, The Progressive Patriot. A Search for Belonging (London, Transworld Publishers, 2006).

Carlet, Yasmine, Stand Down Margaret (Clermont-Ferrand, Editions Mélanie Séteun, 2004).

Cloonan, Martin, Popular Music and the State in the UN: Culture, Trade or Industry? (London, Routledge, 2016 [2007]).

Coles, Richard, Fathomless Riches: Or How I Went From Pop To Pulpit (London, Orion, 2015 [2014]).

Collins, Andrew, Still Suitable for Miners. Billy Bragg: The Official Biography (London, Virgin, 1988).

Denselowe, Robin, When The Music's Over. The Story Of Political Pop (London, Faber and Faber, 1989).

Du Noyer, Paul, 'B. Bragg in “Jobs for Youth”: How to go Top of the Pops and still be super-hip...', New Musical Express (6 April 1985), p. 9.

Frith, Simon and Street, John, 'Rock Against Racism and Red Wedge: from Music to politics, from Politics to Music' in Reebee Garofol (ed), Rockin' the Boat. Mass music and mass movements (Cambridge, MA: South End Press, 1992), pp. 67-80.

Goodyer, Ian, Crisis music. The cultural politics of Rock Against Racism (Manchester, MUP, 2009).

Gray, Marcus, The Clash: Return of the Last Gang in Town (Milwaukee, Hal Leonard, 2004 [2001]).

Hall, Stuart, 'People Aid. A new politics sweeps the land', Marxism Today (July 1986), pp. 10-14.

Harris, John, The Last Party. Britpop, Blair and the Demise of English Rock (London, Harper Perennial 2004 [2002]).

Hewitt, Paolo, Paul Weller. The Changing Man (London, Corgi, 2008 [2007]).

Long, Pat, The History of the NME (London, Portico, 2012).

Lowry, Ray, 'Skinning the system', New Musical Express (6 August 1983), pp. 6-7, 43.

Lynskey, Dorian, 33 Revolutions Per Minute. A History of Protest Songs (London, Faber and Faber, 2010).

Mandelson, Peter, The Third Man. Life at the Heart of New Labour (London, Harper Press, 2010).

Manzoor, Sarfraz, 'The year rock found the power to unite', Guardian (20 April 2008), https:// www.theguardian.com/music/2008/apr/20/popandrock.race (consulted 5 June 2016)

Martin, David, Hewitt, Paolo, Moore, X, Donnell, David et al., 'Vox Pop', New Musical Express (11 June 1983), pp. 12-13.

Red Reg, "A summer of mindless psychedelic has led on to a winter far from grey", Well Red, 9 (1989), p. 2.

Red Reg, 'We're back', Well Red, 10 (1990), p. 2. 
Red Wedge, Register to Vote, Use Your Vote (London, Red Wedge, 1987).

Red Wedge, Move On Up. A Socialist Vision of the Future (London, Red Wedge, 1987).

Red Wedge, A State of Independence (London, Red Wedge, nd),

Red Wedge, The World of Arts. For a World of Difference (London, Red Wedge, nd).

Reed, John, Paul Weller: My Ever Changing Moods, London: Omnibus Press 2005 [1996]).

Renton, Dave, When We Touched The Sky. The Anti-Nazi League 1977-1981 (Cheltenham, New Clarion Press, 2006).

Scarlett, Will, 'Shout to the Top', Well Red, (1989), p. 10.

Shaw, William, ‘Talking Sanity with Madness', Well Red, 1 (1986), pp. 30-31.

Shelton, Syd, 'Rock Against Racism', AnOther (29 September 2015) http://www.anothermag.com/ art-photography/7841/rock-against-racism (consulted 15 June 2016).

Shuker, Roy, Understanding Popular Music (London, Routledge, 2001 [1994]).

Spencer, Neil, 'Labour rock ads spark RAR protest', New Musical Express (28 April 1979), p. 11.

Street, John, 'Red Wedge: another strange story of pop's politics', Critical Quarterly, vol. 3, No. 3

(1988), pp. 79-91.

Sutcliffe, Kevin, 'The Dean Machine', Well Red, 1 (1986), pp. 28-29;

'Wedge world', Well Red, 1 (1986), pp. 7-10.

Swift, Nick, The Housemartins. "Now that's what I call quite good." The Authorised Biography (Hull, Tales From Humberside, 1988).

Thrills Adrian, 'Redheads Under the beds', New Musical Express (23 February 1985), pp. 2-3.

Tranmer, Jeremy, 'Charity, Politics and Publicity: Musicians and the Strike' in Simon Popple and Ian W. MacDonald, Ian W. (eds), Digging the Seam. Popular Cultures (Newcastle: Cambridge Scholars Publishing, 2012), pp. 76-86.

Tranmer, Jeremy, 'Rocking Against Racism: Trotskyism, Communism and Punk in Britain' in Robert Adlington (ed), Red Strains. Music and Communism outside the Communist Bloc (Oxford: Oxford University Press, 2013), pp. 267-282.

Westlake, Martin, Kinnock. The Biography (London, Little, Brown and Company, 2001).

\section{NOTES}

1. In this article, Roy Shuker's brief definition of popular music will be adopted: "commercially mass produced music for a mass market [...] including the variety of genres variously subsumed by terms such as rock'n'roll, rock, pop, dance, hip-hop, and R\&B”. Roy SHUKER, Understanding Popular Music. London: Routledge, 2001 [1994], p. x.

2. This can be explained by a variety of factors. Red Wedge was unable to prevent Labour from losing a third successive general election in 1987 and has consequently suffered, to a certain extent, from what E.P. Thompson famously termed the "enormous condescension of posterity". Moreover, although Red Wedge hoped to modernise Labour's appeal to young people, it defended what was in many ways a relatively traditional view of socialism, one which was thoroughly marginalised in the Labour Party in the 1990s. As a result, there is no nostalgia for Red Wedge within the party and there have been no attempts to resurrect or imitate it. 
3. Simon FRITH and John STREET, "Rock Against Racism and Red Wedge: from Music to politics, from Politics to Music" in Reebee GAROFOL (ed), Rockin' the Boat. Mass music and mass movements, Cambridge, MA: South End Press, 1992, pp. 67-80. John Street also looked at Red Wedge in his individual work. See for example, John STREET, “Red Wedge: another strange story of pop's politics", Critical Quarterly, vol. 3, No. 3, 1988, pp. 79-91.

4. Yasmine CARLET, Stand Down Margaret, Clermont-Ferrand: Editions Mélanie Séteun, 2004, pp. 48-63.

5. Robin DENSELOWE, When The Music's Over. The Story of Political Pop, London, Faber and Faber, 1989, pp. 219-232. John HARRIS, The Last Party. Britpop, Blair and the Demise of English Rock, London: Harper Perennial 2004 [2002]), pp. 196-200. Dorian LYNSKEY, 33 Revolutions Per Minute. A History of Protest Songs, London, Faber and Faber, 2010, pp. 515-524.

6. Andrew COLLINS, Still Suitable for Miners. Billy Bragg: The Official Biography, London, Virgin, 1988, pp. 159-174, pp. 181-186. ; John REED, Paul Weller: My Ever Changing Moods, London: Omnibus Press 2005 [1996]), pp. 180-186. Richard COLES, Fathomless Riches: Or How I Went From Pop To Pulpit, London, Orion, 2015 [2014], pp. 86-92.

7. For example, in Martin Westlake's biography of Neil Kinnock, a single paragraph is given over to Red Wedge. Martin WESTLAKE, Kinnock. The Biography, London: Little, Brown and Company, 2001, pp. 354-355. Although Peter Mandelson frequently visited the Red Wedge office, he does not mention it once in his autobiography. Peter MANDELSON, The Third Man. Life at the Heart of New Labour, London: Harper Press, 2010.

8. Red Wedge's archives are held at the Modern Records Centre of the University of Warwick, while the full run of Well Red can be found at the Working Class Movement Library in Salford.

9. RED WEDGE, The World of Arts. For a World of Difference, London, Red Wedge, nd, p. 2.

10. An Introduction to Red Wedge: Guidelines for MPs, Prospective Parliamentary Candidates and Councillors, nd. p. 1.

11. Driving a Wedge between Factions and Fiction. Office Report, February 1986, p. 9. In practical terms, this gave musicians a dominant role since they were the largest single grouping in Red Wedge.

12. Driving a Wedge between Factions and Fiction. Office Report, February 1986, p. 3.

13. See the internal document Red Wedge notes for party politicians.

14. For example, RED WEDGE, A State of Independence, London: Red Wedge, nd, which presented the overall approach of Red Wedge, and RED WEDGE, Register to Vote, Use Your Vote, London: Red Wedge, 1987.

15. Kevin AINSLEIGH, "Red and Black", Well Red, 1, 1986, pp. 4-5. "Wedge world”, Well Red, 1, 1986, pp. 7-10. Kevin SUTCLIFFE, "The Dean Machine”, Well Red, 1, 1986, pp. 28-29; William SHAW, “Talking Sanity with Madness", Well Red, 1, 1986, pp. 30-31.

16. RED WEDGE, Move On Up. A Socialist Vision of the Future, 1987, p. 11.

17. Ibid., p. 12.

18. The Red Wedge archives contain a Red Wedge employee's resignation letter which stated: “ Words cannot describe the bitterness I felt the night of June $11^{\text {th }}$ for the lack of understanding and downright selfishness of the British people". MSS.281/14/73

19. Paolo HEWITT, Paul Weller. The Changing Man. London: Corgi, 2008 (2007), p. 221.

20. For instance, Robin Denselowe's account of Red Wedge stops with the disappointed reactions to the 1987 election results, while John Harris erroneously states that it was wound up in 1988. DENSELOWE, When the Music's Over, op cit. p. 232. HARRIS, The Last Party, op cit. p. 153.

21. Will SCARLETT, "Shout to the Top", Well Red, 9, 1989, p. 10.

22. RED REG, "We're back", Well Red, 10, 1990, p. 2.

23. RED REG, "A summer of mindless psychedelic has led on to a winter far from grey", Well Red, 9, p. 2. 
24. For a history of RAR, see Ian GOODYER, Crisis music. The cultural politics of Rock Against Racism, Manchester: MUP, 2009.

25. The carnivals were mounted jointly with the Anti-Nazi League, which was more overtly political. For the relationship between the two, see Dave RENTON, When We Touched The Sky. The Anti-Nazi League 1977-1981, Cheltenham: New Clarion Press, 2006, pp. 115-135.

26. Sarfraz MANZOOR, "The year rock found the power to unite", Guardian, 20 April 2008, https://www.theguardian.com/music/2008/apr/20/popandrock.race (consulted 5 June 2016)

27. Pat LONG, The History of the NME, London: Portico, 2012, p. 123.

28. Billy BRAGG, The Progressive Patriot. A Search for Belonging, London: Transworld Publishers, 2006, p. 198.

29. Although musicians expressed political opinions in unprecedented numbers, it is important to bear in mind that most musicians took little interest in political matters and refused to comment on them. Left-wing musicians were therefore a vocal minority.

30. For non-British readers, the UB40 form was the one one needed to fill in to claim unemployment benefit.

31. See for example, Ray LOWRY, "Skinning the system." New Musical Express, 6 August 1983, pp. 6-7, 43; Adrian THRILLS, "Redheads Under the beds." New Musical Express, 23 February 1985, pp. 2-3; Paul DU NOYER, "B. Bragg in 'Jobs for Youth': How to go Top of the Pops and still be superhip..." New Musical Express, 6 April 1985, p. 9.

32. Nick SWIFT, The Housemartins. "Now that's what I call quite good." The Authorised Biography, Hull: Tales From Humberside, 1988, p. 60.

33. For an analysis of the role of musicians during the strike, see Jeremy TRANMER, "Charity, Politics and Publicity: Musicians and the Strike", in Simon POPPLE and Ian W. MacDonald (eds), Digging the Seam. Popular Cultures, Newcastle: Cambridge Scholars Publishing, 2012, pp. 76-86.

34. David MARTIN, Paolo HEWITT, X MOORE, David DONNELL et al., "Vox Pop", New Musical Express, 11 June 1983, pp. 12-13.

35. For a detailed presentation of the SWP's attitude to punk, see Jeremy TRANMER, "Rocking Against Racism: Trotskyism, Communism and Punk in Britain", in Robert ADLINGTON (ed), Red Strains. Music and Communism outside the Communist Bloc, Oxford: Oxford University Press, 2013, pp. 267-282.

36. New Musical Express, 21 April 1979, p. 33. This angered RAR which accused Labour of opportunism. Neil SPENCER, "Labour rock ads spark RAR protest”, New Musical Express, 28 April 1979, p. 11.

37. LYNSKEY, 33 Revolutions Per Minute, op cit. p. 516.

38. COLLINS, Still Suitable for Miners, op cit. pp. 157-158.

39. See for example, Stuart HALL, "People Aid. A new politics sweeps the land", Marxism Today, July 1986, pp. 10-14.

40. FRITH and STREET, "Rock Against Racism and Red Wedge: from Music to politics, from Politics to Music", op cit. p. 67.

41. REED, My Ever Changing Moods, op cit. p. 181.

42. Syd SHELTON, “Rock Against Racism", AnOther, 29 September 2015, http:// www.anothermag.com/art-photography/7841/rock-against-racism (consulted 15 June 2016).

43. Robin DENESELOWE, When The Music's Over. The Story of Political Pop, London, Faber and Faber, 1989 , p. 224.

44. Johnny BLACK, "Red Wedge: bringing Labour Party politics to young music fans", Guardian, 22 April 2015, https://www.theguardian.com/music/2015/apr/22/red-wedge-bringing-labourparty-politics-to-young-music-fans (consulted 10 June 2016)

45. Ibid. 
46. Move On Up' was written and recorded by the American soul artist Curtis Mayfield in 1970. Mayfield had championed the civil rights and black power movements in the 1960s in songs such as 'People get ready' and 'We're a winner'.

47. Marcus GRAY, The Clash: Return of the Last Gang in Town, Milwaukee: Hal Leonard, 2004 (2001), p. 278.

48. Ibid, p. 278.

49. Interim Steering Committee, 1 April 1987, p. 1.

50. HEWITT, Paul Weller. The Changing Man, op cit. p. 222.

51. DENSELOWE, When The Music's Over, op cit. p. 228.

52. CARLET, Stand Down Margaret, op cit. p. 55.

53. HEWITT, Paul Weller. The Changing Man, op cit. p. 223.

54. Robin DENESELOWE, When The Music's Over, op cit. p. 218.

55. Ibid, p. 218.

56. An Introduction to Red Wedge; Guidelines for MPs, Prospective Parliamentary Candidates and Councillors, p. 1.

57. Ibid, p. 2.

58. This may explain why Labour's financial support for Red Wedge was somewhat limited, which was constantly criticised by musicians. See for example, Interim Steering Committee, 1 April 1987, p. 1.

59. Not all left-wing musicians shared their pragmatism. Red Wedge's best-known left-wing critics were the Redskins, who refused to have anything to do with it. The Housemartins adopted a similar position, although they participated in one leg of the 1987 election tour. Red Wedge therefore only represented one strand of the musical opposition to Thatcherism.

60. Red Wedge and By-elections (the minutes of a meeting held at Labour Party heaquarters on 11th June 1986 involving Red Wedge, Arts for Labour and the Labour Party.

61. Martin CLOONAN, Popular Music and the State in the UN: Culture, Trade or Industry?, London: Routledge, 2016 (2007), p. 17.

62. COLLINS, Still Suitable for Miners, , op cit. p. 159.

\section{ABSTRACTS}

During the 1980s, many British musicians expressed criticism of Margaret Thatcher's policies in their music and in interviews with the press. Following the defeat of the miners' strike in 1985, some came to the conclusion that only way they could contribute to defeating the Prime Minister was by supporting the Labour Party. In order to do so, they created Red Wedge, a movement of musicians which tried to persuade young people to vote Labour. Red Wedge attempted to promote new forms of activism for musicians but came up against a number of obstacles, such as structural constraints linked to the nature of the music industry.

Durant les années 1980, de nombreux musiciens britanniques critiquèrent la politique de Margaret Thatcher à travers leur musique et lors d'entretiens accordés à la presse. A la suite de l'échec de la grève des mineurs de 1985, certains d'entre eux en vinrent à conclure que soutenir le Parti travailliste était la seule manière de contribuer à la défaite du Premier ministre. Dans cette perspective, ils créèrent Red Wedge, un mouvement de musiciens qui s'efforça de persuader les jeunes à voter pour les travaillistes. Red Wedge tenta de promouvoir de nouvelles formes de 
militantisme chez les musiciens mais se confronta à un certain nombre d'obstacles et notamment à des contraintes structurelles liées à la nature de l'industrie du disque et à l'inexpérience politique des musiciens.

INDEX

Keywords: Red Wedge, Labour Party, Thatcherism, 1980s, activism, music

Mots-clés: Red Wedge, parti travailliste, thatchérisme, années 1980, militantisme, musique

\section{AUTHOR}

JEREMY TRANMER

Université de Lorraine 